American Journal of Pharmaceutical Education 2012; 76 (4) Article 56.

\title{
VIEWPOINTS
}

\section{Needs-Based Education in the Context of Globalization}

Claire Anderson, BPharm, PhD, ${ }^{\mathrm{a}}$ Ian Bates, BPharm, ${ }^{\mathrm{b}}$ Tina Brock, EdD, BSPharm, ${ }^{\mathrm{c}}$ Andrew Nelson Brown, BPharm, ${ }^{\mathrm{d}}$ Andreia Bruno, PhD, BPharm, ${ }^{\mathrm{e}}$ Billy Futter, Timothy Rennie, PhD, BScPharm, ${ }^{\mathrm{g}}$ and Michael J. Rouse, MPS, BPharm (Hons) ${ }^{\mathrm{h}}$

${ }^{a}$ School of Pharmacy, University of Nottingham, UK

${ }^{\mathrm{b}} \mathrm{UCL}$ School of Pharmacy, London, UK

${ }^{\mathrm{c}}$ San Francisco School of Pharmacy, University of California, CA

${ }^{\mathrm{d} U n i v e r s i t y ~ o f ~ C a n b e r r a, ~ C a n b e r r a, ~ A u s t r a l i a ~}$

${ }^{\mathrm{e}}$ FIP Collaborating Center, UCL School of Pharmacy, UK

${ }^{f}$ Rhodes University, South Africa

${ }^{\mathrm{g}}$ University of Namibia, Namibia

${ }^{\mathrm{h}}$ Accreditation Council for Pharmacy Education, Chicago, IL

Submitted April 5, 2012; accepted April 5, 2012; published May 10, 2012.

While opinion leaders in developed countries are calling for curricula to prepare students for specialized areas of pharmacy, ${ }^{1-4}$ developing countries are seeking patient-centered curricula and public health pharmacy to meet their changing health environments. ${ }^{5}$ In addition, there may be specific needs, especially in settings where tertiary pharmacy education has not been in place previously. ${ }^{6}$

Curricula must better reflect the wide range of career directions that future pharmacists will take in ever-changing health systems. ${ }^{7}$ There is a desire to prepare graduates for a varied and unknown future, but educationalists may not be moving quickly enough toward these goals. ${ }^{8-10}$

There is an emerging challenge to move from curricula that focus on knowledge and skills to curricula that will develop pharmacists as people who will, "think, act, and do things in a way that shows they are truly patientcentered pharmacists." 9 The greater challenge may be to prepare these same pharmacists to take responsibility for their decisions, rather than deferring responsibility to others in the health team, regardless of their practice context.

Globally pharmacy educators continue to face challenges in meeting stakeholder requirements which are made more difficult in developing countries by a lack of resources (human and otherwise), expertise, infrastructure, and the increased pressures of globalization.

The transition to integrated patient-orientated pharmacy services in the developed world has been a factor

Corresponding Author: Andrew Nelson Brown, University of Canberra, Canberra, ACT, Australia 2601. Tel:

+61411137625. Fax: +61411137625. E-mail: Andrew.

Brown@canberra.edu.au of health-system planning and investment in academic and practice orientation and quality assurance over many years. ${ }^{11}$ Developed countries have been the leaders in competency-based pharmacy curricula, which have been a product of these tertiary health care environments.

In contrast, within developing countries the population's access to health services is reduced and primary health care provision is the main aim of the health-care system. The role of pharmacists in these environments is still emerging but trends toward a focus on access to medicines (which is more complicated than in the models described above), as well as on availability, accessibility, affordability, and acceptability. In a number of countries, eg, India and Mexico, pharmacists are also used increasingly in the pharmaceutical industry.

Access to medicines in the developing setting is worsened by a lack of pharmacy education to train new pharmacists who could then provide medicines. There is a large disparity in the global distribution of pharmacists, with Sub-Saharan Africa having some of the poorest density of pharmacists ( $<1$ in 10,000 population), compared to more dense pharmacist populations in countries such as the United States $(9$ per 10,000) and Europe (mean of 9 per 10,000). ${ }^{12}$

In many countries the focus is simply on producing enough pharmacists to meet the basic health care needs of the country, especially in situations where universities are under resourced and pharmacy academics and pharmacy schools are few. Many health systems in developing countries do not recognize pharmacists as part of the integrated health care team, with patient-centred pharmaceutical care just emerging, and the perceived status of pharmacists still well below that of their medical peers. ${ }^{13}$ In fact, in countries with few pharmacists, the initial focus 


\section{American Journal of Pharmaceutical Education 2012; 76 (4) Article 56.}

may need to be on appropriate pharmaceutical management, where improvements in pharmaceutical supply are needed to achieve the health-related millennium development goals. ${ }^{14}$

The introduction of doctor of pharmacy degree programs or similar programs in developing and transition countries has not been without its critics, with education quality; opportunities and environments for clinical learning experiences; job opportunities; and professional inequalities being at the center of the debate. ${ }^{15-17}$ These criticisms are set against a backdrop of expectant globalization and the desire to attain a perceived global standard. ${ }^{15-17}$

Globalization brings internationalization of education as universities widen their borders beyond conventional country or regional boundaries, and the workforce seeks the ability to move more freely between countries. ${ }^{18}$ Within the international environment there is the occasional call for standardized competencies, curricula, and courses for pharmacists, but considering the variation of pharmacy practice and education capacity this may not be a feasible nor a desirable endpoint. ${ }^{19}$

However, this does not mitigate the desirable goal of ensuring every "global" patient has access to equitable (and high-quality) medicines expertise provided by pharmacist practitioners. For example, recent work by the multilateral EU PHARMINE (Pharmacy in Europe) consortium has demonstrated that consensus on competencies across countries and sectors can be achieved. ${ }^{20}$ Emerging work by the International Pharmaceutical Federation Pharmacy Education Taskforce (FIP-PET) is also indicating that variance in expectations of foundation level competencies is not as great as widely feared..$^{21,27}$

FIP-PET continues to promote needs-based education as a model for developing pharmacy education globally. ${ }^{14,22-24}$ The strategy calls for an assessment of the needs of the community and then development, or adaptation, of supporting educational systems accordingly. Implementing such a needs-based approach requires ongoing consultation and co-operative partnerships between all stakeholders within countries, and within institutions.

The culture in traditional academic environments may resist the implementation of outcomes-based education, preferring to focus on scientific fields of expertise in preference to an integrated curriculum that is directed towards developing professional competencies (ie, developing research portfolios and leadership in their particular field are strong motivators for academic progression).

In addition, without any focused stakeholder policy, there will be a mismatch of expectation after graduation, particularly when graduates have undergone more detailed clinical training only to discover a lack of interest in developing (or using) new roles and frustration that these "expected" roles are not present in the health system. ${ }^{13}$

FIP-PET has been developing tools that enable global action to improve pharmacy education, but also allow local application to ensure that specific country and regional needs are met. Specifically, the ongoing development of a global pharmacy competency framework $^{25}$ and recent release of the global framework for quality assurance ${ }^{26}$ are 2 tools that can be used by countries and institutions as they seek to transform pharmacy education.

Globalization is increasing the tendency for the pharmacy community to consider itself part of a "global village" of pharmacy practice. As we embrace this future, let us ensure we consider the needs-based education requirements of each country context, keeping our focus on what would be best for our patients.

\section{REFERENCES}

1. Marken PA. Personalized medicine: are we preparing our students for the knowledge revolution? Am J Pharm Educ. 2011;75(3): Article 48.

2. McKinnon R, Anderson C. Transforming pharmaceutical education to accelerate the acceptance and implementation of personalized medicine. Am J Pharm Educ. 2011;75(6):Article 107.

3. Hertig J. New practitioners and the pharmacy practice model initiative: our opportunity to define the future. Am J Health-Syst Pharm. 2011;68(12):1074-1076.

4. Truong J. Where are the postgraduate programs for tomorrow's education administrative leaders? Am J Pharm Educ. 2011;75(9): Article 192.

5. Hassali MA. Challenges and future directions for public health pharmacy education in developing countries. Am J Pharm Educ. 2011;75(10):Article 195.

6. Rennie TW, Haoses-Gorases L, Lates J, Mabirizi D, Nyarang'o P, Sagwa E. Sustaining Namibia: improving the nation's health through sustainable pharmacy competency. Intl Pharm J. 2011;27(1):21-24. 7. DiPiro JT. Preparing our students for the many opportunities in pharmacy. Am J Pharm Educ. 2011;75(9):Article 170.

8. Carter RA. The new american pharmacist. Am J Pharm Educ. 2011;75(9):Article 172.

9. Noble C, Shaw PN, Nissen L, Coombes I, O'Brien M. Curriculum for uncertainty: certainty may not be the answer. Am J Pharm Educ. 2011;75(1):13a.

10. O'Donoghue N. Separating fact from fiction. (Cover story). Pharm Times. 2011;77(7):14-18.

11. Saleh Abrika OS, Ahmad Hassali MA, Abduelkarem AR. Social pharmacy courses are often neglected in the developing world. Am $J$ Pharm Educ. 2011;75(4):65b.

12. FIP. 2009 FIP Global Pharmacy Workforce Report. 2009 [cited 10th February 2012]. http://www.fip.org/programmesandprojects pharmacyeducationtaskforce_humanresources?filename $=$ fip $/ 2009 \%$ 20GPWR\%20cover\%20contents\%20foreword.pdf. Accessed April 24, 2012.

13. Lim Z, Anderson C, McGrath S. Professional skills development in a resource-poor setting: the case of pharmacy in Malawi. Intl $J$ Educ Develop. 2012 In Press. 


\section{American Journal of Pharmaceutical Education 2012; 76 (4) Article 56.}

14. Anderson C, Brock T, Bates I, Rouse M, Marriott J, Manasse H, et al. Transforming health professional education. Am J Pharm Educ. 2011;75(2):Article 22.

15. Jamshed S, Babar ZUD, Masood I. The PharmD degree in developing countries. Am J Pharm Educ. 2007;71(6):Article 125. 16. Ahmed SI, Ahmad Hassali MA. The controversy of PharmD degree. Am J Pharm Educ. 2008;72(3):Article 71.

17. Khan TM, Anwar M, Mueen Ahmed KK. A perspective for clinical pharmacy curriculum development and validation in Asian developing nations. (Cover story). J Young Pharmacists. 2011;3(2): 151-154.

18. Lee W. Learning for the future: the emergence of lifelong learning and the internationalisation of education as the fourth way? Educ Res Policy Pract. 2012;11(1):53-64.

19. Sekhon BS, Kamboj SR. Pharmaceutical education and careerñan overview. J Pharm Educ Res. 2011;2(1):73-86.

20. PHARMINE European consortium. http://www.pharmine.org/. Accessed April 24, 2012.

21. Bruno A, Bates I, Brock T, Anderson C. Towards a global competency framework. Am J Pharm Educ. 2010;74(3):

Article 56.
22. Anderson C, Bates I, Beck D, Brock T, Futter B, Mercer H, et al. The WHO UNESCO FIP Pharmacy Education Taskforce: enabling concerted and collective global action. Am J Pharm Educ. 2008;72(6): Article 127.

23. Anderson C, Bates I, Beck D, Brock TP, Futter B, Mercer H, et al. The WHO UNESCO FIP Pharmacy Education Taskforce.

Hum Resour Health. 2009;7:45.

24. Anderson C, Bates I, Futter B, Gal D, Rouse M. Global perspectives of pharmacy education and practice. World Med Health Policy. 2010;2(2):5-18.

25. FIP-PET. A Global Competency Framwork Draft Version 2010. 2010 [cited 12th November 2010]; http:/www.fip.org/files/fip/ PharmacyEducation/GbCF_booklet_Feb_2012.pdf. Accessed April 24, 2012.

26. FIP. FIP statement of policy quality assurance of pharmacy education. 2009 [cited; http://www.fip.org/www/uploads/database_ file.php?id=302\&table_id=. Accessed April 24, 2012.

27. Bruno A, Bates I, Brock T. Validating Global Competencies for Pharmacy Education. Abstract presented at the $71^{\text {st }}$ International Pharmaceutical Federation (FIP) Congress, Hyderabad, India. September 2011. 